\title{
Effects of Cholecystokinin Octapeptide on the Release of Growth Hormone from the Perifused Bovine Pituitary In Vitro
}

\author{
Tsutomu Hashizume and Shigeto Kanematsu \\ Faculty of Agriculture, Iwate University, Morioka-shi 020
}

(Received April 24, 1990)

\begin{abstract}
The effect of cholecystokinin octapeptide (CCK-8) was studied on the release of growth hormone $(\mathrm{GH})$ from perifused adenohypophyses of steers. Perifusion with media containing $10^{-7}, 10^{-8}$ and $10^{-9} \mathrm{M} \mathrm{CCK}-8$ for 90 min significantly increased the mean $\mathrm{GH}$ concentrations during the treatments by $\Delta 7.36(\mathrm{P}<0.01), \Delta 13.31(\mathrm{P}<0.01)$ and $\Delta 5.64$ $(\mathrm{P}<0.05) \mathrm{ng} / \mathrm{m} l$ respectively compared with the control group. There was no significant difference in the rates of increase in GH among the three molar perifusion groups. The present results indicate that $\mathrm{CCK}-8$ acts directly on the adenohypophysis to stimulate release of $\mathrm{GH}$ in cattle.
\end{abstract}

Anim. Sci. Technol. (Jpn.) 62 (3) : 243-246, 1991

Key words : cholecystokinin, growth hormone, cattle, pituitary

Growth hormone (GH) secretion is well known to be regulated by two hormones, somatostatin, an inhibitory regulatory factor and growth hormone releasing factor ${ }^{11}$. It is reported, however, that some brain peptides also play a role in the control of $\mathrm{GH}$ secretion ${ }^{6}$. Cholecystokinin octapeptide (CCK8 ) is considered to be one of these peptides in rats $^{5-7,10)}$. Namely, VIJAYAN et al. ${ }^{10)}$ reported that the plasma level of $\mathrm{GH}$ increased within $15 \mathrm{~min}$ after injection of CCK 8 into the third ventricle of rats. MAtsumura et al. ${ }^{5)}$ also reported that intravenous injection of $\mathrm{CCK}-8$ increased in plasma $\mathrm{GH}$ level after 10 and 20 min in rats. It is not certain, however, whether the CCK stimulates release of $\mathrm{GH}$ indirectly through the hypothalamus ${ }^{10)}$ or directly on the adenohypophysis ${ }^{5,7)}$. And the effect of CCK on GH secretion in domestic animals also has not been elucidated. In our earlier investigation ${ }^{32}$, we demonstrated that VIP, one of another brain peptides, acts directly on the adenohypophysis to release $\mathrm{GH}$ in cows.

In the present study, we examined the effect of $\mathrm{CCK}-8$ on the secretion of $\mathrm{GH}$ from the adenohypophysis of steers, using an in vitro perifusion system of anterior pituitary tissues.

\section{Materials and Methods}

The adenohypophysis were removed from 9 Holstein steers (age in 17-18 months) at a local slaughter house and were transported to the laboratory in Krebs-Ringer bicarbonate solution to which was added $1.8 \mathrm{mg}$ glucose $/ \mathrm{m} l, 0.5 \mathrm{mg}$ bacitracin $/ \mathrm{m} l, 1.0 \mathrm{mg}$ bovine serum albumin $/ \mathrm{m} l, 0.1 \mathrm{mg}$ streptomycin $/ \mathrm{m} l$ and 100 IU penicillin $/ \mathrm{m} l$ (modified KRB solution) at $5^{\circ} \mathrm{C}$ within $2 \mathrm{~h}$. The hypophysis were sagittally cut into halves before they were immersed into the modified KRB solution. The pituitary tissues used were medial part of the anterior lobe and they were sectioned into small cubes of $1.5 \mathrm{~mm}$ dimensions. Five cubes of the 
anterior pituitary tissue were loaded into a small plastic chamber of $0.2 \mathrm{~m} l$ size and were perifused at $38^{\circ} \mathrm{C}$, in a modified $\mathrm{KRB}$ solution saturated with $95 \% \quad \mathrm{O}_{2}$ and $5 \% \quad \mathrm{CO}_{2}$. After equilibration for $3 \mathrm{~h}$, the effluent was collected in $3 \mathrm{~m} l$ fractions at $10 \mathrm{~min}$ intervals at a flow rate of $18 \mathrm{ml} / \mathrm{h}$. Six samples of the effluent were collected over a period of $1 \mathrm{~h}$ for determinations of basal GH levels. Then solution containing various concentrations $\left(10^{-7}\right.$, $10^{-8}$ and $10^{-9} \mathrm{M}$ ) of $\mathrm{CCK}^{-8}$ (sulfated form, Peptide Institute Inc., Osaka, Japan) and the medium alone (control) were perifused for the next $1.5 \mathrm{~h}$ and nine samples of the effluent were collected during these periods. At the termination of the experiment, a modified solution containing high potassium ion $(123.2 \mathrm{mM} \mathrm{KCl}$ in KRB solution) was perifused to recognize the viability of the tissues used. Samples were stored at $-20^{\circ} \mathrm{C}$ until assayed.

$\mathrm{GH}$ in effluent fractions were measured by radioimmunoassays as described previously ${ }^{4}$. In this assay, the intra- and inter-assay coefficients of variation were 6.6 and $17.7 \%$, respectively. Least detectable value of assays was $7.97 \mathrm{ng} / \mathrm{ml}$. Values were expressed as means and standards errors. Each value from nine samples during the $1.5 \mathrm{~h}-\mathrm{CCK}$ treatment were also expressed as net changes of $\mathrm{GH}$ $(\Delta \mathrm{GH} \mathrm{ng} / \mathrm{m} l$ ) from the mean of six samples obtained prior to CCK-8 infusion. For statistical analysis the mean $\mathrm{GH}$ concentrations during infusion of $\mathrm{CCK}-8$ from 5 to 6 perifusions (nine determinations each) were compared with the mean basal levels and the mean values of the control group. Data were used when the pituitary tissues released GH markedly in response to high potassium ion solution. Statistical comparisons were made using the Student's t test after Bartlett's test for uniformity of the variances.

\section{Results}

$\mathrm{GH}$ release from perifused bovine pituitary tissues in response to different CCK- 8 concentrations are shown in Table 1. In the control group there was no significant difference between the mean basal $\mathrm{GH}$ levels and the mean $\mathrm{GH}$ value, that was obtained from the subsequent perifusions with medium alone, during which period CCK -8 was perifused in other groups. Perifusion with the media containing $10^{-7}, 10^{-8}$ and $10^{-9} \mathrm{M}$ CCK for $90 \mathrm{~min}$ significantly increased $\mathrm{GH}$ concentrations during the treatments compared with the each basal GH levels $(P<0.05)$. At the termination of the perifusion all pituitary tissues used in the experiment released GH markedly in response to high potassium ion solution (Table 1).

As shown in Fig. 1, perifusion with the media containing $10^{-7}, 10^{-8}$ and $10^{-9} \mathrm{M} \mathrm{CCK}^{-8}$ for $90 \mathrm{~min}$ significantly increased the mean $\mathrm{GH}$ concentrations during the treatments by $\Delta 7.36$

Table 1. GH release from perifused bovine pituitary tissues to different CCK- 8 concentrations and high potassium ion solution.

\begin{tabular}{|c|c|c|c|}
\hline \multirow{2}{*}{ CCK -8 conc. } & \multirow{2}{*}{ Basal levels } & \multicolumn{2}{|c|}{ Perifusion of } \\
\hline & & $\mathrm{CCK}-8$ & High potassium ion \\
\hline Controls $(6)^{*}$ & $10.26 \pm 0.90^{\mathrm{a}}$ & $9.36 \pm 3.92^{\mathrm{a}}$ & $49.30 \pm 5.42^{b}$ \\
\hline $10^{-7} \mathrm{M}(6)$ & $14.82 \pm 0.91^{\mathrm{a}}$ & $22.07 \pm 2.36^{b}$ & $48.55 \pm 9.22^{\mathrm{c}}$ \\
\hline $10^{-8} \quad M(5)$ & $14.20 \pm 0.72^{\mathrm{a}}$ & $28.16 \pm 4.00^{b}$ & $49.88 \pm 9.67^{c}$ \\
\hline $10^{-9} \quad \mathrm{M}(5)$ & $16.12 \pm 0.87^{\mathrm{a}}$ & $21.19 \pm 2.01^{b}$ & $53.00 \pm 10.23^{c}$ \\
\hline
\end{tabular}

Values represent the mean $\pm \mathrm{SE}$ of $\mathrm{GH}$ levels ( $\mathrm{ng} / \mathrm{ml} / 10 \mathrm{~min}$ ) before perifusion of CCK-8 (basal levels) and during perifusion of CCK-8 or high potassium ion solution.

* : Numbers in parenthesis represent number of determinations.

$a, b, c$ : Values on the same line with different superscripts are significantly different! $(P<0.05)$. 


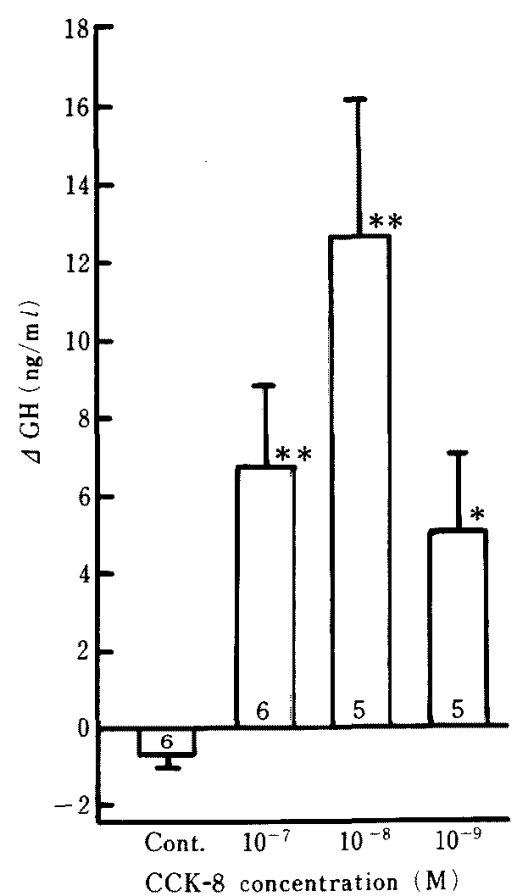

Fig. 1. Secretory response of in vitro $\mathrm{GH}$ release from perifused bovine pituitary tissues to different $\mathrm{CCK}-8$ concentrations. Values represent the mean $\pm \mathrm{SE}$ of the total $\Delta \mathrm{GH}$ levels during perifusion of $\mathrm{CCK}-8$. Numbers at the base of each bar represent number of determinations. $\mathrm{GH}$ levels of the $\mathrm{CCK}-8$ perifused groups are significantly greater than that of control group. ${ }^{*}:(\mathrm{P}<0.05),{ }^{* *}:(\mathrm{P}$ $<0.01$ ).

$(\mathrm{P}<0.01), \triangle 13.31(\mathrm{P}<0.01)$ and $45.64(\mathrm{P}<$ $0.05) \mathrm{ng} / \mathrm{m} l$ respectively compared with the control group. The GH released in the medium in the $10^{-8} \mathrm{M}$ group tended to increase compared with another molar groups, but they were not significantly different each other (Fig. 1).

\section{Discussion}

The present study demonstrated that CCK -8 induced GH release directly from the anterior pituitary in vitro in cattle. Heretofore, effects of $\mathrm{CCK}$ on the release of pituitary $\mathrm{GH}$ have never been reported in domestic animals in vivo as well as in vitro. VIJAYAN et al. ${ }^{10)}$ suggested that CCK has no direct action on the anterior pituitary, acting indirectly on the hypothalamus to release anterior pituitary hormones. But MORLEy et al. ${ }^{7}$ reported that CCK stimulated $\mathrm{GH}$ release directly from rat $\mathrm{GH}_{3}$ cells, and similarly MATsumura et al. ${ }^{5)}$ reported that CCK stimulated GH release from dispersed cells of rat anterior pituitary. The results of the present investigation are consistent with the observations of MORLEY et $a l .{ }^{7)}$ and MAtsumura et $a l . .^{5}$.

The GH releasing effect of CCK- 8 from the anterior pituitary could be seen at a dose as low as $10^{-9} \mathrm{M}$ perifusion group. It is reported, however, that $\mathrm{CCK}-8$ at a concentration of $10^{-11} \mathrm{M}$ could induce $\mathrm{GH}$ release from anterior pituitary dispersed cells in rats ${ }^{5}$. Therefore, further studies in consideration of lower doses are also necessary in cattle.

CCK is widely distributed in the hypothalamus, hypophysis and pituitary stalk ${ }^{2,8}$. CCK receptors are detected in the brain ${ }^{97}$ and also in the hypophysis ${ }^{11}$. CCK stimulates $\mathrm{GH}$ release in vivo ${ }^{5,10)}$ as well as in vitro ${ }^{5,7)}$. These findings may represent an intimate relationship of brain CCK with pituitary GH secretion. It remains to be determined what effects of the CCK would have on GRF and somatostatin.

\section{Acknowledgments}

The authors wish to thank to Dr. T. JoHKE, National Institute of Animal Industry, Japan for providing antiserum to $\mathrm{bGH}$ and Professor K. WakABAYASHI, the Institute of Endocrinology, Gunma University, Japan for providing goat anti-monkey IgG serum to bGH and monkey serum. The authors are also indebted to NIDDK and National Hormone and Pituitary Program, USA for providing bGH (USDA bGH-B 1) for standard preparation and iodination. We also express our sincere appreciation to Mr. Y. ORIKASA, one of our laboratory's students, for help with hormone assays. 


\title{
HaShIZUME and KANEMATSU
}

\section{References}

1) Baile, C.A. and F.C. Buonomo, Growth hormone-releasing factor on pituitary function, growth, and lactation. J. Dairy Sci., 70 : 467-473. 1987.

2) Beinfeld, M.C., D.K. Meyer, R.L. Eskay, R.T. JENSEN and M.J. Brownstein, The distribution of cholecystokinin immunoreactivity in the central nervous system of the rat as determined by radioimmunoassay. Brain Res., 212 : 51-57. 1981

3) Hashizume, T., N. OOta and S. KaneMATSU, Direct effects of VIP on the release of growth hormone from the superfused bovine pituitary in vitro. Jpn. J. Zootech. Sci., 60 : 689-693. 1989.

4) JoHke, T., Effects of TRH on circulating growth hormone, prolactin and triiodothyronine levels in the bovine. Endocrinol. Japon., 25: 19-26. 1978.

5) Matsumura, M., A. Yamanoi, S. YamaMoto, H. MORI and S. SaIto, In vivo and in vitro effects of cholecystokinin octapeptide on the release of growth hormone in rats. Horm. metabol. Res., 16:626-630. 1984.

6) McCANn, S.M., Control of anterior pitui- tary hormone release by brain peptides. Neuroendocrinology, 31 : 355-363. 1980.

7) Morlex, J.E., S. Melmed, J. Briggs, H.E. Carlson, J.M. Hershman, T.E. Solomon, C. Lamers and D.A. Damassa, Cholecystokinin octapeptide releases growth hormone from the pituitary in vitro. Life Sci., 25 : 1201-1206. 1979.

8) REHFELD, J.F., Localization of gastrins to neuro- and adenohypophysis. Nature, 271 : 771-773. 1978.

9) Satto, A., H. Sankaran, I.D. Goldfine and J.A. WILLIAMS, Cholecystokinin receptors in the brain: Characterization and distribution. Science, 208: 1155-1156. 1980.

10) VIJAYAN, E., W.K. SAMSON and S.M. MCCANN, In vivo and in vitro effects of cholecystokinin on gonadotropin, prolactin, growth hormone and thyrotropin release in the rat. Brain Res., 172:295302. 1979.

11) Weiner, R.I., P.R. Findell and C. KorDON, Role of classic and peptide neuromediators in the neuroendocrine regulation of LH and prolactin. in The Physiology of Reproduction vol. I. (KNOBHL, E. and J.D. NeILL eds.) 1235-1281. Raven Press. New York. 1988.

\section{牛の下垂体の in vitro 潅流系における成長ホルモン放出に 及ぼすコレシストキニンオクタペプチドの効果}

\author{
橋爪 力・兼松重任
}

岩手大学農学部, 盛岡市 020

コレシストキニンオクタペプチド（CCK-8）が牛の成長ホルモン $(\mathrm{GH})$ の放出に及就す影響につ

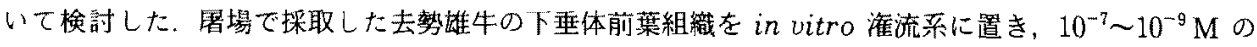
CCK-8 を 90 分間旅流し，潅流液中の $\mathrm{GH}$ 濃度の変化を調べた，CCK-8 $\left(10^{-7} \sim 10^{-9} \mathrm{M}\right)$ を潅流する 之海流液中の平均 $\mathrm{GH}$ 濃度は海流前の基礎濃度に比心有意に增加した（P<0.05）。また潅流期間中の 平均 $\mathrm{GH}$ 漊度は $10^{-7} ， 10^{-8} お よ ひ ゙ ~ 10^{-9} \mathrm{M}$ において，対照区に比べそれぞれ $\Delta 7.36(\mathrm{P}<0.01)$ ， $\Delta 13.31 （ \mathrm{P}<0.01 ）$ および $\Delta 5.64(\mathrm{P}<0.05) \mathrm{ng} / \mathrm{ml}$ 有意に增加した。 この $\mathrm{GH}$ 濃度の增加割合に は CCK-8の添加隂度による差は認められなかった。本研究の結果は CCK-8は GH の放出機構に促 進的に作用すること，またその機能は下垂体に直接作用して起こることを示している.

日畜会報, $62(3) ： 243-246 ， 1991$ 